clevelandfed.org/research/workpaper/1995/wp9510.pdf

Working Paper 9510

\title{
OPTIMAL TAXATION OF CAPITAL INCOME IN A GROWTH MODEL WITH MONOPOLY PROFITS
}

by Jang-Ting Guo and Kevin J. Lansing

Jang-Ting Guo is a professor of economics at the University of California, Riverside, and Kevin J. Lansing is an economist at the Federal Reserve Bank of Cleveland. For helpful comments, the authors thank Steven Cassou, Stephen Cecchetti, Roger Farmer, Finn Kydland, Randall Wright, seminar participants at the 1995 Western Economic Association meetings, and two anonymous referees.

Working papers of the Federal Reserve Bank of Cleveland are preliminary materials circulated to stimulate discussion and critical comment. The views stated herein are those of the authors and are not necessarily those of the Federal Reserve Bank of Cleveland or of the Board of Governors of the Federal Reserve System. 


\begin{abstract}
This paper shows that the optimal steady-state tax on capital income in a neoclassical growth model can be positive, negative, or zero, depending crucially on the level of monopoly profits and the degree to which profits can be taxed. With an empirically plausible level of profits, the model implies that the optimal steady-state tax on capital can range between -6 percent and 24 percent, depending on the structure of dividend taxation. Similarly, we find that the available welfare gain of switching from the existing U.S. tax policy to a revenue-neutral optimal tax policy can range between 0.8 percent and 3.9 percent of steady-state output.
\end{abstract}




\section{Introduction}

An important issue for U.S. policymakers is whether capital gains should be taxed as ordinary income (as they are now) or be given some form of tax-favored treatment. Judd (1985) and Chamley (1986) show that, in the long run, the standard neoclassical growth model implies that capital income should not be taxed at all, that is, the optimal steady-state tax on capital income is zero. Based on this result, other researchers, such as Lucas (1990), Cooley and Hansen (1992), and McGrattan, Rogerson, and Wright (1993) estimate that there exist large unexploited gains to eliminating the U.S. capital tax.

In this paper, we augment the standard model to allow for the possibility of monopoly profits and show that the optimal steady-state tax on capital income can be positive, negative, or zero. The optimal tax rate depends crucially on the level of monopoly profits and the degree to which profits can be taxed. In particular, we adopt a model of the production environment developed by Benhabib and Farmer (1994) in which producers of intermediate goods possess a degree of monopoly power that can be characterized by a single parameter. The model embeds the perfect competition environment assumed by Judd (1985) and Chamley (1986) as a special case.

The consideration of monopoly power introduces two competing effects that interact to determine the optimal steady-state tax on capital income. First, households underinvest relative to the socially optimal level because the interest rate that governs their investment decisions is less than the marginal product of capital. This "underinvestment effect" represents the classic inefficiency of a monopoly, and results in lower long-run levels of capital and output in comparison to the perfectly competitive case. To correct this inefficiency, the government can subsidize capital accumulation (and stimulate output) by imposing a negative tax rate on capital income.

The second effect derives from the fact that firms with monopoly power earn pure economic profits. Since profits do not affect household decisions at the margin, the government would like to tax profits at a rate of 100 percent, thereby allowing other distortionary taxes to be reduced. When the tax authority does not distinguish between profits and other types of capital income (as we assume), then the capital tax can also function as a tax on profits, but one with an endogenous upper bound. We show that the strength of this "profit effect" depends on the structure of dividend taxation. If profits are taxed at both the firm level and the household level (in what is called a double-taxation-of-dividends policy), 
then the capital tax collects a large fraction of revenue from profits. This strengthens the profit effect and motivates the government to choose a higher capital tax for a given level of monopoly profits.

Our model allows for a rich set of possibilities regarding the optimal steady-state tax on capital income. For example, if the profit effect is stronger than the underinvestment effect, then the optimal tax rate is positive. This result complements recent research by Jones, Manuelli, and Rossi (1993), Aiyagari (1994), and İmrohoroğlu (1994), who provide alternative theoretical justifications for a positive optimal tax rate on capital in the long run. If the profit effect exactly cancels the underinvestment effect, then the optimal tax rate can be zero even in an economy without perfect competition. If profits can be completely taxed away by some separate instrument (or if the firm's fixed costs imply zero profits), then the underinvestment effect will still remain and the optimal tax rate is negative. The perfect competition result obtained by Judd (1985) and Chamley (1986) represents a special case of our model, in which neither of the two effects described above is present.

The ambiguity regarding the sign of the optimal long-run capital tax is directly analogous to the findings of Stiglitz and Dasgupta (1971). They find that the optimal commodity tax policy for a monopolistic industry with profits will generally include both differential taxes and subsidies. The link between differential commodity taxation and the capital tax in our model is very direct; a positive (negative) capital tax implies that future consumption goods are taxed at a higher (lower) rate than present consumption goods.

Given the inconclusive nature of the theory, we undertake a quantitative assessment of the optimal tax policy in a calibrated version of our model. When the profit-to-output ratio is 5 percent (a typical value for U.S. manufacturing industries), we find that the optimal steady-state tax on capital income can range between -6 percent and 24 percent, depending on the level of dividend taxation. Similarly, we find that the available welfare gain of switching from the existing U.S. tax policy to a revenue-neutral optimal tax policy can range between 0.8 percent and 3.9 percent of steady-state output. Higher levels of dividend taxation imply lower welfare gains because revenue that was previously obtained by a tax on profits must now be replaced with a higher distortionary tax on labor. Thus, our results suggest that previous estimates regarding the benefits of reducing the U.S capital tax may be overstated. 
The remainder of this paper is organized as follows. Section 2 describes the model. In section 3 , we derive the expressions that determine the optimal steady-state tax on capital income. Sections 4 and 5 discuss computation issues and the choice of parameter values. Section 6 presents our quantitative results, and section 7 concludes.

\section{The Model}

The model economy consists of three types of agents: households, firms, and the government. The production environment differs from the standard competitive framework used by Judd (1985) and Chamley (1986). In particular, we allow for the possibility that intermediate goods producers possess monopoly power. This implies that firms can realize positive economic profits even though the finalgoods sector of the economy is perfectly competitive. As owners of the firms, households receive net profits in the form of dividends. Various options regarding the taxation of these dividends are considered.

\subsection{The Household's Problem}

There is a large number of identical, infinitely lived households, each of which maximizes a stream of discounted utilities over sequences of consumption and leisure:

$$
\max \sum_{t=0}^{\infty} \beta^{t}\left[U\left(c_{t}, h_{t}\right)+V\left(g_{t}\right)\right], \quad 0<\beta<1
$$

The within-period utility function $U(\cdot)$ is increasing in private consumption $c_{t}$ and decreasing in hours worked $h_{t}$. The parameter $\beta$ is the constant discount factor. The function $V(\cdot)$ is increasing in $g_{t}$, where $g_{t}$ represents per capita public consumption goods which are determined outside of households' control. Both $U(\cdot)$ and $V(\cdot)$ are assumed to be continuously differentiable, bounded, and concave. The additive separability in $g_{t}$ implies that public consumption does not affect the marginal utility of private consumption, a specification supported by parameter estimates in McGrattan, Rogerson, and Wright (1993). Although this specification is not necessary for our results, it simplifies the computations because $V(\cdot)$ can be ignored when deriving the household optimization conditions. 
The representative household faces the following within-period budget constraint:

$$
c_{t}+x_{t}+b_{t+1} \leq\left(1-\tau_{h t}\right) w_{t} h_{t}+\left(1-\tau_{k t}\right)\left(r_{t} k_{t}+\hat{t}_{t}+r_{b t} b_{t}\right)+\delta \tau_{k t} k_{t}+b_{t}, \quad k_{0}, b_{0} \text { given, }
$$

where $x_{t}$ is private investment, $k_{t}$ is private capital, and $b_{t+1}$ represents one-period, real government bonds carried into period $t+1$ by the household. Households derive income by supplying labor and capital services to firms at rental rates $w_{t}$ and $r_{t}$. Two additional sources of household income are the firm's net profits $\hat{t}_{t}$, which are distributed to households as dividends, and the interest earned on government bonds $r_{b t} b_{t}$.

We impose a restriction that prevents the government from taxing away monopoly profits. In particular, we assume that the tax authority does not distinguish between profits and other types of capital income. As a result, the tax on capital income also functions as a tax on profits, but one with an endogenous upper bound. This scenario is reflected in equation (2), where net profits $\hat{\pi}_{t}$, capital rental income $r_{t} k_{t}$, and bond interest $r_{b t} b_{t}$ are all taxed at the same rate $\tau_{k t}$. Labor income is taxed at the rate $\tau_{h t}$. The term $\delta \tau_{k t} k_{t}$ represents a depreciation allowance, where $\delta$ is the constant depreciation rate. Households view tax rates, wages, interest rates, and dividends as determined outside their control.

The following equation describes the law of motion for the capital stock:

$$
k_{t+1}=(1-\delta) k_{t}+x_{t}
$$

The household first-order conditions with respect to the indicated variables and the associated transversality conditions (TVC) are: 


$$
\begin{array}{cl}
c_{t}: & \lambda_{t}=U_{c}\left(c_{t}, h_{t}\right) \\
h_{t}: & \lambda_{t}\left(1-\tau_{h t}\right) w_{t}=-U_{h}\left(c_{t}, h_{t}\right) \\
k_{t+1}: & \lambda_{t}=\beta \lambda_{t+1}\left[\left(1-\tau_{k t+1}\right)\left(r_{t+1}-\delta\right)+1\right] \\
b_{t+1}: & \lambda_{t}=\beta \lambda_{t+1}\left[\left(1-\tau_{k t+1}\right) r_{b t+1}+1\right] \\
\text { TVC: } & \lim _{t \rightarrow \infty} \beta^{t} \lambda_{t} k_{t+1}=0, \quad \lim _{t \rightarrow \infty} \beta^{t} \lambda_{t} b_{t+1}=0,
\end{array}
$$

where $\lambda_{t}$ is the Lagrange multiplier associated with the budget constraint (2). The transversality conditions ensure that (2) can be transformed into an infinite-horizon, present-value budget constraint.

\subsection{Production Environment}

Our description of the production environment closely follows the model developed by Benhabib and Farmer (1994). There exists a continuum of intermediate goods $y_{i t}, i \in[0,1]$, and a unique final good $y_{t}$ that is produced using the following constant-returns-to-scale technology:

$$
y_{t}=\left(\int_{0}^{1} y_{i t}^{\chi} d i\right)^{1 / \chi}, \quad 0<\chi \leq 1 .
$$

Final-goods producers choose $y_{i t}$ in order to maximize profits: $y_{t}-\int_{0}^{1} p_{i t} y_{i t} d i$, where $p_{i t}$ is the relative price of the $i$ th intermediate good. Profit maximization implies $p_{i t}=\left(y_{i t} / y_{t}\right)^{x-1}$, which is the demand function for intermediate goods. When $\chi<1$, intermediate goods producers perceive a downward sloping demand curve. In this case, the firm earns an economic profit that is distributed to households in the form of dividends. When $\chi=1$, however, intermediate goods are perfect substitutes in the production of the final good, and the intermediate sector becomes perfectly competitive. The technology for producing intermediate goods is given by

$$
y_{i t}=k_{i t}^{\alpha} h_{i t}^{1-\alpha}, \quad 0<\alpha<1,
$$

where $k_{i t}$ and $h_{i t}$ are the capital and labor inputs of the $i$ th firm. The decision problem of an 
intermediate-goods producer can be summarized as

$$
\begin{aligned}
& \max _{k_{i t}, h_{i t}}\left(1-\tau_{k t}\right)^{\gamma-1}\left(p_{i t} y_{i t}-r_{t} k_{i t}-w_{t} h_{i t}\right), \quad \gamma=\{0,1,2\}, \\
& \text { subject to: } \quad p_{i t}=\left(y_{i t} / y_{t}\right)^{\alpha-1}, \quad y_{i t}=k_{i t}^{\alpha} h_{i t}^{1-\alpha} .
\end{aligned}
$$

In (7), we allow for the possibility that the firm's profits may be taxed directly. The government's use of the tax rate $\tau_{k t}$ for this purpose implies that the tax authority does not distinguish between households and firms when assessing taxes on capital income. As before, this ensures that profits will not be completely taxed away. When $\gamma=2$, profits are initially taxed at the firm level and then taxed again as dividends at the household level. We refer to this case as a double taxation of dividends policy. When $\gamma=1$, dividends are taxed only at household level. When $\gamma=0$, the effective tax rate on dividends is zero. In reduced form, the $\gamma=0$ case can be viewed as capturing the possibility that the tax authority does not observe monopoly profits. The first-order conditions from (7) are:

$$
\begin{gathered}
r_{t}=\frac{\chi \alpha p_{i t} y_{i t}}{k_{i t}}, \\
w_{t}=\frac{\chi(1-\alpha) p_{i t} y_{i t}}{h_{i t}} .
\end{gathered}
$$

Restricting our attention to a symmetric equilibrium implies $k_{i t}=k_{t}, h_{i t}=h_{t}$, and $p_{i t}=p_{t}$, for all $i$. In this case, (5) and (6) imply that the aggregate production function is

$$
y_{t}=k_{t}^{\alpha} h_{t}^{1-\alpha}
$$

The assumption that the final-goods sector is perfectly competitive implies $y_{t}-\int_{0}^{1} p_{i t} y_{i t} d i=0$. Substituting $y_{i t}=p_{i t}{ }^{1-\chi} y_{t}$ into this expression and applying symmetry yields $p_{i t}=p_{t}=1$. Equations (8a) and $(8 \mathrm{~b})$ can then be used to obtain the following expressions for the equilibrium rental rate on capital and the real wage: 


$$
\begin{aligned}
r_{t} & =\chi \alpha y_{t} / k_{t}, \\
w_{t} & =\chi(1-\alpha) y_{t} / h_{t} .
\end{aligned}
$$

Notice that when $\chi<1$, the rental rate $r_{t}$ is less than the marginal product of capital $\alpha y_{t} / k_{t}$ implied by equation (9). The after-tax profits in the intermediate-goods sector are given by:

$$
\hat{\pi}_{t}=\left(1-\tau_{k t}\right)^{\gamma-1}(1-\chi) y_{t}
$$

\subsection{The Government's Problem}

The government chooses an optimal program of taxes, borrowing, and public expenditures to maximize the discounted utility of the household. To avoid time inconsistency problems, we assume that the government can commit to a sequence of policies announced at $t=0$. Following the approach of Chari, Christiano, and Kehoe (1994a), we further assume that $\tau_{k 0}$ and $r_{b 0}$ are specified exogenously such that tax revenue collected at $t=0$ cannot finance all future expenditures. If the initial levy on privatesector assets is sufficiently large, then the government chooses $\tau_{h t}=\tau_{k t}=0$ for some $t>\hat{t}$. This case is not very interesting because after period $\hat{t}$, the model looks identical to one with lump-sum taxes. In per capita terms, the government's budget constraint in period $t$ is

$$
g_{t}+b_{t}\left(1+r_{b t}\right)=b_{t+1}+\tau_{h t} w_{t} h_{t}+\tau_{k t}\left[\left(r_{t}-\delta\right) k_{t}+r_{b t} b_{t}\right]+\left[1-\left(1-\tau_{k t}\right)^{\gamma}\right](1-\chi) y_{t}
$$

The summation of the household budget constraint (2) and the government budget constraint (12) yields the following per capita resource constraint for the economy:

$$
y_{t}=c_{t}+g_{t}+x_{t}
$$

Because the resource constraint and the government budget constraint are not independent equations, equation (13) can be used in place of (12) in formulating the government's problem.

As a condition for equilibrium, government policy must take into account the rational responses of the private sector, as summarized by (2), (3), (4), (10), and (11). These equations can be conveniently summarized by the following "implementability constraint": 
clevelandfed.org/research/workpaper/1995/wp9510.pdf

$$
\begin{gathered}
\sum_{t=1}^{\infty} \beta^{t}\left[U_{c}\left(c_{t}, h_{t}\right) c_{t}+U_{h}\left(c_{t}, h_{t}\right) h_{t}-\lambda_{t}\left(\frac{\lambda_{t-1} /\left(\beta \lambda_{t}\right)-1}{\chi \alpha y_{t} / k_{1}-\delta}\right)^{\gamma}(1-\chi) y_{t}\right]+U_{c}\left(c_{0}, h_{0}\right) c_{0}+U_{h}\left(c_{0}, h_{0}\right) h_{0} \\
-\lambda_{0}\left\{\left(1-\tau_{k 0}\right)^{\gamma}(1-\chi) y_{0}+\left[\left(1-\tau_{k 0}\right)\left(r_{0}-\delta\right)+1\right] k_{0}+\left[\left(1-\tau_{k 0}\right) r_{b 0}+1\right] b_{0}\right\}=0 .
\end{gathered}
$$

Equation (14) is obtained by substituting the first-order conditions of the household and the firm into the present-value household budget constraint. ${ }^{1}$ Since $\tau_{k 0}$ and $r_{b 0}$ are specified exogenously, the government's problem can be represented as choosing a set of allocations $c_{t}, h_{t}, g_{t}$, and $k_{t+1}$, for all $t$ to maximize household utility (1) subject to (13) and (14), with $\lambda_{t}=U_{c}\left(c_{t}, h_{t}\right)$. Given the optimal allocations, the appropriate set of prices $r_{t}$ and $w_{t}$, and policy variables $\tau_{h t}, \tau_{k t}$, and $r_{b t}$ that decentralize them can be computed using the profit-maximization conditions (10), the household first-order conditions (4), and the household budget constraint (2). For example, the optimal allocations define $\lambda_{t}$ and $w_{t}$ from equations (4a) and (10b). Given $\lambda_{t}$ and $w_{t},(4 \mathrm{~b})$ defines the government's optimal choice for $\tau_{h t}$.

The government's problem can be written as

$$
\begin{aligned}
& \max _{c_{t}, h_{t}, g_{1}, t=1} \sum_{t=1}^{\infty} \beta^{t}\left\{U\left(c_{t}, h_{t}\right)+V\left(g_{t}\right)+\Lambda\left[U_{c}\left(c_{t}, h_{t}\right) c_{t}+U_{h}\left(c_{t}, h_{t}\right) h_{t}-\lambda_{t}\left(\frac{\lambda_{t-1} /\left(\beta \lambda_{t}\right)-1}{\chi \alpha y_{t} / k_{t}-\delta}\right)^{\gamma}(1-\chi) y_{t}\right]\right\}+U\left(c_{0}, h_{0}\right)+V\left(g_{0}\right) \\
& k_{t+v}, \lambda_{t} \\
& +\Lambda\left\{U_{c}\left(c_{0}, h_{0}\right) c_{0}+U_{h}\left(c_{0}, h_{0}\right) h_{0}-\lambda_{0}\left(1-\tau_{k 0}\right)^{\gamma}(1-\chi) y_{0}-\lambda_{0}\left[\left(1-\tau_{k 0}\right)\left(r_{0}-\delta\right)+1\right] k_{0}-\lambda_{0}\left[\left(1-\tau_{k 0}\right) r_{b 0}+1\right] b_{0}\right\},
\end{aligned}
$$

subject to

$$
\begin{aligned}
& g_{t}=y_{t}-c_{t}-k_{t+1}+k_{t}(1-\delta), \\
& y_{t}=k_{t}^{\alpha} h_{t}^{1-\alpha}, \\
& \lambda_{t}=U_{c}\left(c_{t}, h_{t}\right),
\end{aligned}
$$

with $k_{0}, b_{0}, \tau_{k 0}$, and $r_{b 0}$ given. The Lagrange multiplier $\Lambda$ associated with (14) is determined endogenously at $t=0$ and is constant over time.

Since the government's problem for $t \geq 1$ is recursive, the solution for $t \geq 1$ can be characterized

${ }^{1}$ More specifically, equation (14) is obtained as follows: Multiply both sides of the household budget constraint (2) by $\lambda_{t}$, substitute in (4a)-(4d), (10), and (11), iterate the resulting expression forward and sum over time, and then apply the transversality conditions (4e). 
by a set of stationary decision rules for the allocations $c_{t}\left(s_{t}, \Lambda\right), h_{t}\left(s_{t}, \Lambda\right), g_{t}\left(s_{t}, \Lambda\right), k_{t+1}\left(s_{t}, \Lambda\right)$, $\lambda_{t}\left(s_{t}, \Lambda\right)$, where $s_{t}=\left\{k_{t}, \lambda_{t-1}\right\}$. Given these decision rules, a stationary decision rule for the government bond allocation $b_{t+1}\left(s_{t}, \Lambda\right)$ can be computed as the solution to the following recursive equation:

$$
\lambda_{t}\left(k_{t+1}+b_{t+1}\right)=\beta\left[U_{c}\left(c_{t+1}, h_{t+1}\right) c_{t+1}+U_{h}\left(c_{t+1}, h_{t+1}\right) h_{t+1}-\lambda_{t+1}\left(\frac{\lambda_{t} /\left(\beta \lambda_{t+1}\right)-1}{\chi \alpha y_{t+1} / k_{t+1}-\delta}\right)^{\gamma}(1-\chi) y_{t+1}+\lambda_{t+1}\left(k_{t+2}+b_{t+2}\right)\right] .
$$

Equation (16) is the household budget constraint at $t+1$ after substituting in the first-order conditions of the private sector. At $t=0$, the government chooses $c_{0}, h_{0}, g_{0}, k_{1}$, and $\lambda_{0}$. The $t=0$ allocations, together with the stationary decision rules for $t \geq 1$, determine $\Lambda$ for a given set of initial conditions. $^{2}$

\section{The Optimal Steady-State Tax on Capital Income}

In this section, we derive some expressions to show how the optimal steady-state tax on capital income $\tau_{k}^{*}$ depends on the level of profits and the degree to which profits can be taxed. The government's first-order condition with respect to $k_{t+1}$ from (15) is

$$
\begin{aligned}
& -V_{g}\left(g_{t}\right)+\beta V_{g}\left(g_{t+1}\right)\left(r_{t+1} / \chi+1-\delta\right)- \\
& \beta \Lambda \lambda_{t+1} \frac{(1-\chi)}{\chi} \frac{\left[\lambda_{t} /\left(\beta \lambda_{t+1}\right)-1\right]^{\gamma}}{\left(r_{t+1}-\delta\right)^{\gamma+1}}\left[r_{t+1}^{2}(1+\gamma(1-\alpha) / \alpha)-r_{t+1} \delta\right]=0 .
\end{aligned}
$$

Omitting time subscripts and dividing by $\beta$ yields the following steady-state version of equation (17), where $p=1 / \beta-1$ is the rate of time preference.

$$
V_{g}(g)(r / \chi-\delta-\rho)-\Lambda \lambda \frac{(1-\chi)}{\chi} \frac{\rho^{\gamma} r}{(r-\delta)^{\gamma+1}}[r(1+\gamma(1-\alpha) / \alpha)-\delta]=0
$$

In steady state, the household's first-order condition with respect to $k_{t+1}$, equation (4c), can be written as:

\footnotetext{
${ }^{2}$ See Chari, Christiano, and Kehoe (1994a,b) for more details regarding the solution of the government's problem.
} 


$$
(r-\delta)\left(1-\tau_{k}\right)-\rho=0 .
$$

When $\chi=1$, profits are zero and (18) simplifies to $r-\delta-\rho=0$ (since $V_{g}(g)>0$ ). Comparing this expression to (19) implies $\tau_{k}^{*}=0$, which is the result obtained by Judd (1985) and Chamley (1986). When $\chi<1$, however, there are two competing effects that interact to determine $\tau_{k}^{*}$. First, the rental rate on capital $r$ which governs household investment decisions is now less than the marginal product of capital $r / \chi$. This effect is reflected in the first term of (18) and implies that households underinvest relative to the socially optimal level. To correct this inefficiency, the government can subsidize capital accumulation by choosing $\tau_{k}^{*}<0$. The second term in (18) represents an offsetting effect that is driven by the level of profits and the degree to which profits can be taxed. Since profits do not affect household decisions at the margin, the government would like to tax profits as much as possible to obtain nondistortionary revenue. Choosing $\tau_{k}^{*}>0$ accomplishes this objective in varying degrees, depending on the value of $\gamma$. As $\gamma$ increases, the capital tax collects a larger fraction of revenue from profits. As the quantitative analysis will show, this fact motivates the government to choose a higher capital tax and a lower labor tax for a given value of $\chi$.

Since $\chi$ appears in both the first and second terms of (18), theoretical conclusions regarding the sign of $\tau_{k}^{*}$ cannot be made except in the special case of $\chi=1$. Depending on the relative importance of the two effects, the optimal steady-state tax on capital can be positive, negative, or zero. The underinvestment effect may not be present if profits derive from a different source, such as productive government expenditures. In this case, Jones, Manuelli, and Rossi (1993) show that the incentive to tax profits (the profit effect) implies that the optimal steady-state tax on capital is positive.

\section{Computation Procedure}

Given the inconclusive nature of the theory, we now turn to a quantitative assessment of the optimal capital tax in a calibrated version of our model. The steady-state allocations implied by (15) depend on parameter values (which are described below) and the endogenous Lagrange multiplier $\Lambda$, which is computed as follows. First, given an initial guess for $\Lambda$, we compute the steady-state allocations $c, h, g, k$, and $\lambda$ from the first-order conditions of (15) with respect to $c_{t}, h_{t}, g_{t}, k_{t+1}$, and $\lambda_{t}$. We then 
use the steady-state version of (15) to compute the steady-state level of government debt $b$. We repeat this procedure, adjusting $\Lambda$ until we obtain a desired ratio of steady-state debt to output. The initial level of debt $b_{0}$ that is consistent with $\Lambda$ and $b$ can be computed using the first-order conditions of (15) with respect to $c_{0}, h_{0}, g_{0}, k_{1}$, and $\lambda_{0}$, together with the stationary decision rules for $t \geq 1$, the household budget constraint (2) evaluated at $t=0$ and $t=1$, and the initial conditions $k_{0}, \tau_{k 0}$, and $r_{b 0}$.

Once the optimal steady-state allocations are known, we use (10a), (10b), (4b), and (4c) to determine the optimal steady-state tax policy $\left\{\tau_{k}{ }^{*}, \tau_{h}{ }^{*}\right\}$ that decentralizes the allocations. This procedure is repeated over a range of values for $\chi$ and $\gamma$. In each case, we compute the welfare loss from switching to a "naive" policy that sets $\tau_{k}=0$ and adjusts $\tau_{h}$ to achieve the same levels of $g$ and $b$ as the optimal policy. We also compute the welfare gain of switching from the existing U.S. tax policy to an optimal policy, again holding the levels of $g$ and $b$ constant. $^{3}$ We use the steady-state level of the household's within-period utility function as our basic welfare measure. This facilitates a simple comparison between our results and those of Lucas (1990) and Cooley and Hansen (1992), who consider the welfare effects of capital taxation in models with zero profits. Since a time period in the model is taken to be one year (consistent with the frequency of most government fiscal decisions), the change in steady-state utility across policies can be readily translated into an annual gain or loss and expressed as percentage of total output.

A more comprehensive welfare analysis would obviously need to take into account the dynamic transition between steady states. However, during the first period of the transition, the government in our model has a strong incentive to impose a heavy tax on the existing stock of household assets in order to minimize distortions. Chari, Christiano, and Kehoe (1994a) show that the welfare gains from this initial levy tend to dominate any differences between final steady states. ${ }^{4}$ Although this scenario provides an interesting motivation for tax reform, it is doubtful that confiscatory taxes of this kind are

\footnotetext{
${ }^{3}$ In particular, we follow the approach of Lucas (1990) and assume that the net change in debt is zero along the transition path between steady states. This implies that tax rates along the transition path are set such that the implementability constraint is satisfied. Alternatively, we could assume that lump-sum taxes are available during the first period of the transition to satisfy the implementability constraint. See Chari, Christiano, and Kehoe (1994b) for a more detailed discussion of this point.

${ }^{4}$ Even though $\tau_{k 0}$ is specified exogenously, $\tau_{k 1}$ tends to be much higher than the optimal steady-state value $\tau_{k}{ }^{*}$. In addition, the large positive value of $\tau_{k 1}$ typically implies $\tau_{h 0}<0$.
} 
politically feasible. Lucas (1990), Cooley and Hansen (1992), and Mendoza and Tesar (1995) adopt an alternative approach to transitional dynamics by assuming that shifts in tax rates between steady states are exogenous. They obtain a quite different result--that transitions involve a welfare loss. This loss reduces the available gains from moving to a more desirable steady state. Given the many ways in which transitions can be modeled, we have chosen to abstract from these issues and report results only from steady-state welfare analysis. Our results must therefore be qualified to the extent that transitions between steady states produce significant benefits or costs.

\section{Calibration}

Parameters are assigned values based on empirically observed features of postwar U.S. data. The discount factor $\beta(=0.962)$ implies a real rate of interest of 4 percent. The household's within-period utility function is specified as

$$
U\left(c_{t}, h_{t}\right)+V\left(g_{t}\right)=\log \left(c_{t}\right)-A h_{t}+B \log \left(g_{t}\right), \quad A, B>0,
$$

where the linearity in hours worked draws on the formulation of indivisible labor described by Rogerson (1988) and Hansen (1985). This means that all fluctuations in total labor hours are due to changes in the number of workers employed, as opposed to variations in hours per worker. ${ }^{5}$ The parameter $A$ $(=2.48)$ is chosen such that the fraction of time spent working is approximately equal to 0.3 . The value of $B(=0.346)$ is chosen to yield a steady-state ratio $g / y$ close to 0.22 . The private capital depreciation rate $\delta(=0.067)$ is estimated by a least-squares regression of $x_{t}-\left(k_{t+1}-k_{t}\right)$ on $k_{t} \cdot{ }^{6}$ The Lagrange multiplier $\Lambda$ is set to achieve a steady-state ratio $b / y=0.37$ under the optimal policy. This is the average level of U.S. federal debt held by the public as a fraction of GNP from 1954 to 1992 . The steady-state values of $g$ and $b$ under the optimal policy are then used as exogenous inputs to compute the steady-state allocations under the $\tau_{k}=0$ policy.

\footnotetext{
${ }^{5}$ In postwar U.S. data, about two-thirds of the variance in total hours is due to changes in the number of workers. See Kydland and Prescott (1990).

${ }^{6}$ The capital and investment series are in 1987 dollars from Fixed Reproducible Tangible Wealth in the United States, U.S. Department of Commerce (1993). The series for $k_{t}$ and $x_{t}$ include business equipment and structures, consumer durables, and residential components. The "capital input" measure of the net stock was used for all capital data.
} 
To compute the welfare gain of switching from the existing U.S. tax policy to an optimal policy, we follow Cooley and Hansen (1992) and take U.S tax policy to be $\tau_{k}=0.50$ and $\tau_{h}=0.23$. The steadystate level of government debt under the U.S. policy is specified exogenously such that $b / y=0.37$. We then determine the steady-state value of $g$ as a residual such that the government budget constraint (12) is satisfied. To compute $\tau_{k}{ }^{*}$ and $\tau_{h}{ }^{*}$ under the revenue-neutral optimal policy, we adjust the Lagrange multiplier $\Lambda$ to achieve the same level of steady-state debt as the U.S policy and treat the required level of government spending $g$ as an exogenous constraint. ${ }^{\top}$

We examine a range of values for the parameter $\chi$, which determines the steady-state ratio of monopoly profits to output. The profit ratio $s_{\pi}$ is linked to the markup of price over marginal cost according to the formula

$$
\mathrm{v}=\frac{p}{m c}\left(1-s_{\pi}\right)
$$

where $v$ represents the degree of returns to scale in the intermediate-goods sector. Our use of a constantreturns-to-scale specification in (6) implies $v=1$ and $s_{\pi}=1-\chi$. Using data on U.S. manufacturing industries over the period 1953-1985, Basu and Fernald (1994a) obtain a point estimate of $v=1.03$, but this is not statistically different from 1. Basu and Fernald (1994b) find that the typical manufacturing industry has an average profit ratio of about 0.05 . Based on these results, we choose $\chi=0.95$ as our baseline value, which implies $p / m c=1.05$. In the computations, we examine profits ratios over the range 0 to 0.13 .

The shares of total output received by capital and labor in the model are $\chi \alpha$ and $\chi(1-\alpha)$, respectively. Given the baseline value of $\chi$, we set $\alpha=0.34$ such that capital's share is 0.32 and labor's share is 0.63 . These values lie within the ranges estimated by Christiano (1988) for the postwar U.S. economy. Finally, since dividends are subject to double taxation under the U.S. tax code, we choose $\gamma=2$ as our baseline.

\footnotetext{
${ }^{7}$ The government's first-order conditions from (15) must be modified slightly for this experiment to allow for the fact that $g_{t}$ under the optimal policy is no longer endogenous. This can be done very simply by replacing the marginal utility of public consumption $V_{g}\left(g_{t}\right)$ with $\mu_{t}$, where $\mu_{t}$ is the Lagrange multiplier associated with the resource constraint (13).
} 


\section{Quantitative Results}

Table 1 and figures 1-3 show the optimal steady-state tax rates over a range of profit ratios and degrees of dividend taxation. When 1- $\chi=0$, figures 1-3 each indicate that $\tau_{k}{ }^{*}=0$, consistent with the results of Judd (1985) and Chamley (1986). Figure 1 shows that when dividends are not taxed $(\gamma=0)$, $\tau_{k}{ }^{*}$ becomes increasingly negative as the profit ratio rises. In this case, the underinvestment effect from the first term in equation (18) dominates the profit effect associated with the second term. At the baseline profit ratio, the model implies $\tau_{k}^{*}=-0.057$ (see table 1 ). When $\gamma$ equals 1 or 2 , however, the profit effect dominates and $\tau_{k}^{*}$ becomes increasingly positive as the profit ratio rises (figures 2 and 3 ). Moreover, table 1 shows that higher values of $\gamma$ cause $\tau_{k}^{*}$ to increase relative to $\tau_{h}{ }^{*}$. As noted earlier, a higher $\gamma$ implies that the capital tax collects a larger fraction of revenue from profits. Since profits do not distort household decisions, this calls for a higher capital tax, thereby allowing the distortionary tax on labor to be reduced.

At the baseline values of $1-\chi=0.05$ and $\gamma=2$, table 1 indicates that the optimal tax policy is $\tau_{k}{ }^{*}=0.236$ and $\tau_{h}{ }^{*}=0.279$. It is interesting to compare these values to some tax rate estimates for the U.S. economy. Jorgenson and Sullivan (1981) estimate an average effective corporate tax rate of 0.30 for the period 1947-1980. Barro and Sahasakul (1986) estimate an average marginal tax rate on labor income of 0.27 for the period 1947-1983. Sample average estimates by McGrattan, Rogerson, and Wright (1993) are $\tau_{k}=0.57$ and $\tau_{h}=0.23$ for the period 1947-87, while Mendoza, Razin, and Tesar (1994) estimate $\tau_{k}=0.43$ and $\tau_{h}=0.25$ over the period 1965-1988. In general, the U.S. tax rate on capital income appears to be higher than the optimal value of $\tau_{k}^{*}=0.236$ implied by our baseline model. However, we note that our model abstracts from some important considerations which, if taken into account, could increase the optimal tax rate on capital to a value which is closer to U.S. estimates. Jones, Manuelli and Rossi (1993) show that rents associated with productive public goods can give rise to a positive optimal tax rate on capital in the long run. In models without profits, Aiyagari (1994) and İmrohoroğlu (1994) show that a positive optimal tax rate can also be obtained by introducing borrowing constraints and idiosyncratic income shocks among heterogeneous agents.

Figure 4 plots the welfare cost of switching to a naive policy that sets $\tau_{k}=0$ and maintains $g$ and $b$ at the levels implied by the optimal policy. The welfare cost increases rapidly as a function of 
profits when $\gamma=2$, but stays very close to zero when $\gamma=0$. This shows that the structure of dividend taxation can have dramatic effects on household welfare. This is not surprising, since changes in $\gamma$ affect the government's ability to obtain nondistortionary revenue by means of a tax on profits. ${ }^{8}$ Starting from the baseline optimal policy, the welfare cost of eliminating the capital tax is about 1.6 percent of total output (see table 1). This figure translates to an annual loss of $\$ 407$ per person in $1994 .^{9}$

In models without profits, Lucas (1990), Cooley and Hansen (1992), and McGrattan, Rogerson, and Wright (1993) all estimate large available gains from eliminating the U.S. capital income tax. Excluding transitional dynamics, Lucas reports that steady-state consumption increases by 4.2 percent, while McGrattan, Rogerson, and Wright report an increase of 9 percent. Cooley and Hansen report a welfare gain of 7.8 percent of steady-state output. ${ }^{10}$ Table 2 computes the available welfare gains of switching from the existing U.S. tax policy to an optimal policy, holding revenue constant. The requirement to maintain revenue neutrality pushes up the optimal tax rates in comparison to the values reported earlier in table 1.

In table 2 , the available gains depend crucially on the value of $\gamma$. When $\gamma=0$, the gains are large, equal to 3.88 percent of steady-state output. In this case, the U.S. policy of $\tau_{k}=0.50$ is very far from the optimal policy of $\tau_{k}{ }^{*}=0.016$. When $\gamma$ equals 1 or 2 , however, the available welfare gains are less than 1 percent of steady-state output. The gains are much lower in these two cases because revenue that was previously obtained by a tax on profits must now be replaced with a higher tax on labor. If tax rates are considered to be exogenous during the transition between steady states, then these welfare gains are likely to be even lower, and could even turn into welfare losses. This experiment shows that previous claims regarding the benefits of reducing the U.S. capital tax may be overstated.

\footnotetext{
${ }^{8}$ See Guo and Lansing (1995) for a more comprehensive analysis of the effects of tax structure on household welfare.

${ }^{9}$ This number is based on a nominal GNP of $\$ 6,729$ billion and total U.S. population of 260.7 million in 1994.

${ }^{10}$ To compute these gains, Lucas uses a value of 0.36 for the U.S. tax rate on capital income, while McGrattan, Rogerson, and Wright use 0.57 , and Cooley and Hansen use 0.50 .
} 


\section{Concluding Remarks}

This paper has shown that the introduction of monopoly power in an otherwise standard neoclassical growth model creates a theoretical ambiguity regarding the sign of the optimal steady-state tax on capital income. The optimal tax rate in the long run can be positive, negative, or zero, depending on the relative strength of two competing forces, which we label as the underinvestment effect and the profit effect. In particular, the underinvestment effect supports the use of a negative tax rate on capital income to induce monopolistic firms to produce the socially optimal level of output. The profit effect supports the use of a positive tax rate on capital income to minimize distortions in the financing of government spending.

In the quantitative section of the paper, we found that empirically plausible values for the model's parameters imply that the profit effect dominates such that the optimal tax rate is positive. In applying our model to the important policy question of whether or not the U.S. capital tax should be reduced, we found that the welfare gains from such a policy can be large or small, depending on the structure of dividend taxation. 


\section{REFERENCES}

AIYAGARI, S. R. (1994). "Optimal Capital Income Taxation̈ with Incomplete Markets, Borrowing Constraints, and Constant Discounting," Federal Reserve Bank of Minneapolis, Working Paper No. 508.

BARRO, R. J. and C. SAHASAKUL. (1986). "Average Marginal Tax Rates from Social Security and the Individual Income Tax," Journal of Business, 59, 555-566.

BASU, S. and J. G. FERNALD. (1994a). "Constant Returns and Small Markups in U.S. Manufacturing," International Finance Discussion Paper No. 483, Board of Governors of the Federal Reserve System.

(1994b). "Are Apparent Productive Spillovers a Figment of Specification Error?" International Finance Discussion Paper No. 463, Board of Governors of the Federal Reserve System.

BENHABIB, J. and R. E. A. FARMER. (1994). "Indeterminacy and Increasing Returns," Journal of Economic Theory, $63,19-41$.

CHAMLEY, C. P. (1986). "Optimal Taxation of Income in General-Equilibrium with Infinite Lives," Econometrica, 54, 607-622.

CHARI, V. V., L. J. CHRISTIANO, and P. J. KEHOE. (1994a). "Optimal Fiscal Policy in a Business Cycle Model,"Journal of Political Economy, 102, 617-652.

. (1994b) "Policy Analysis in Business Cycle Models," in T. Cooley, ed., Frontiers of Business Cycle Research. Princeton, N.J.: Princeton University Press, 355-391.

CHRISTIANO, L. J. (1988). "Why Does Inventory Investment Fluctuate So Much?" Journal of Monetary Economics, 21, 247-280.

COOLEY, T. F. and G. D. HANSEN. (1992). "Tax Distortions in a Neoclassical Monetary Economy," Journal of Economic Theory, 58, 290-316.

GUO, J. T. and K. J. LANSING. (1995). "Tax Structure, Welfare, and Stability in a Model of Optimal Fiscal Policy," University of California Riverside and Federal Reserve Bank of Cleveland, unpublished manuscript.

HANSEN, G. D. (1985). "Indivisible Labor and the Business Cycle," Journal of Monetary Economics, 16, 309-327.

IMROHOROĞLU, S. (1994). "A Quantitative Analysis of Optimal Tax Structure Under Incomplete Markets," University of Southern California, unpublished manuscript.

JONES, L. E., R. MANUELLI, and P. E. ROSSI. (1993). "On the Optimal Taxation of Capital Income," National Bureau of Economic Research, Working Paper No. 4525.

JORGENSON, D. and M. A. SULLIVAN. (1981). "Inflation and Corporate Capital Recovery," in C.R. Hulten, ed., Depreciation, Inflation, and the Taxation of Income from Capital. Washington, D.C.: Urban Institute Press.

JUDD, K. L. (1985). "Redistributive Taxation in a Simple Perfect Foresight Model," Journal of Public Economics, 28, 59-83.

KYDLAND, F. E. and E. C. PRESCOTT. (1990). "Business Cycles: Real Facts and a Monetary Myth," Federal Reserve Bank of Minneapolis, Quarterly Review, Spring, 3-18.

LUCAS, R. E., Jr. (1990). "Supply Side Economics: An Analytical Review," Oxford Economic Papers, 42, 293-316.

MCGRATTAN, E. R., R. ROGERSON, and R. WRIGHT. (1993). "Household Production and Taxation in the Stochastic Growth Model," Federal Reserve Bank of Minneapolis, Staff Report No. 166. 
MENDOZA, E. G., A. RAZIN, and L. L. TESAR. (1994). "Effective Tax Rates in Macroeconomics: CrossCountry Estimates of Tax Rates on Factor Incomes and Consumption," Journal of Monetary Economics, 34, 297-323.

MENDOZA, E. G. and L. L. TESAR. (1995). "Supply Side Economics in a Global Economy," International Finance Discussion Paper No. 507, Board of Governors of the Federal Reserve System.

RAMSEY, F. P. (1927). "A Contribution to the Theory of Taxation," Economic Journal, 37, 47-61.

ROGERSON, R. (1988). "Indivisible Labor, Lotteries, and Equilibrium," Journal of Monetary Economics, 21, 3-16.

STIGLITZ, J. and P. DASGUPTA. (1971). "Differential Taxation, Public Goods, and Economic Efficiency," Review of Economic Studies, 38, 151-174. 
Table 1: Optimal Steady-State Tax Rates and Welfare Comparison with $\tau_{k}=0$ Policy

\begin{tabular}{|c|c|c|c|c|c|c|}
\hline \multirow[b]{2}{*}{ Variable } & \multicolumn{3}{|c|}{ Profit Ratio $=1-\chi=0.05$} & \multicolumn{3}{|c|}{ Profit Ratio $=1-\chi=0.10$} \\
\hline & $\gamma=0$ & $\gamma=1$ & $\gamma=2$ & $\gamma=0$ & $\gamma=1$ & $\gamma=2$ \\
\hline$\tau_{k}^{*}$ & -0.057 & 0.188 & 0.236 & -0.088 & 0.293 & 0.315 \\
\hline$\tau_{h}^{*}$ & 0.346 & 0.301 & 0.279 & 0.357 & 0.267 & 0.232 \\
\hline $\begin{array}{l}\text { Labor tax } \\
\text { with } \tau_{k}=0\end{array}$ & 0.336 & 0.363 & 0.382 & 0.341 & 0.419 & 0.471 \\
\hline $\begin{array}{c}\text { Welfare loss } \\
\text { from } \tau_{k}=0 \text { policy }\end{array}$ & $0.079 \%$ & $0.500 \%$ & $1.576 \%$ & $0.059 \%$ & $3.452 \%$ & $7.731 \%$ \\
\hline
\end{tabular}

${ }^{\text {a }}$ The welfare loss is defined as $\Delta U /(\lambda y)$, where $\Delta U$ is the change in steady-state utility and $\lambda$ and $y$ are the steady-state values associated with the optimal policy.

Source: Authors' calculations.

Table 2: Available Welfare Gains from Reducing U.S. Capital Tax

\begin{tabular}{cccc}
\hline \hline Variable & \multicolumn{2}{c}{ Profit Ratio $=1-\chi=0.05$} \\
\hline$\tau_{k}^{*}$ (new policy) & $\gamma=0$ & $\gamma=1$ & $\gamma=2$ \\
$\tau_{h}^{*}$ (new policy) & 0.016 & 0.332 & 0.358 \\
$\begin{array}{c}\text { Welfare change } \\
\text { from U.S. policy of } \\
\tau_{k}=0.50 \text { and } \tau_{h}=0.23^{\mathrm{a}}\end{array}$ & 0.347 & 0.316 & 0.308 \\
\hline
\end{tabular}

${ }^{\text {a }}$ The welfare change is defined as $\Delta U /\left(\lambda_{y}\right)$, where $\Delta U=U_{\text {New }}-U_{U . s .}$ and $\lambda$ and $y$ are the steady-state values associated with the U.S. policy.

Source: Authors' calculations. 
Fig 1: TAX RATES vs PROFIT RATIO Zero Tax on Dividends $\gamma=0$

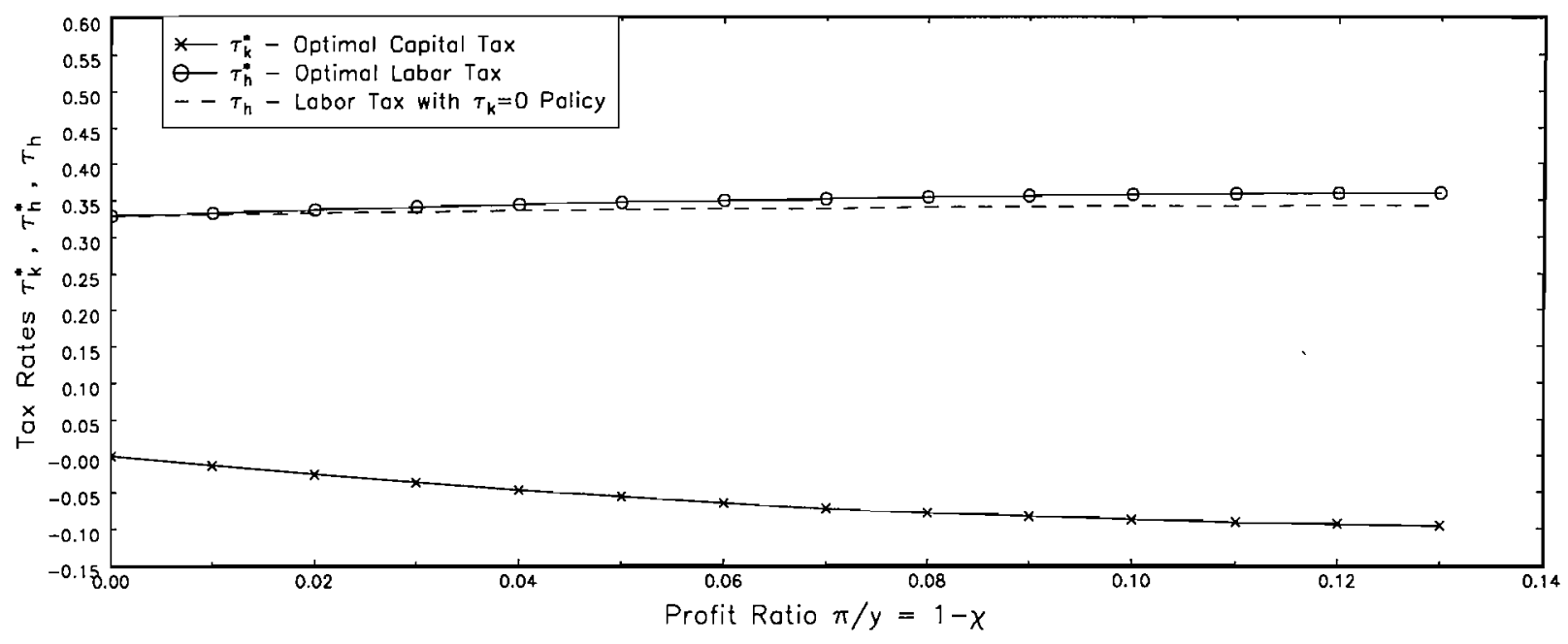

Fig 2: TAX RATES vs PROFIT RATIO

Single Tax an Dividends $\gamma=1$

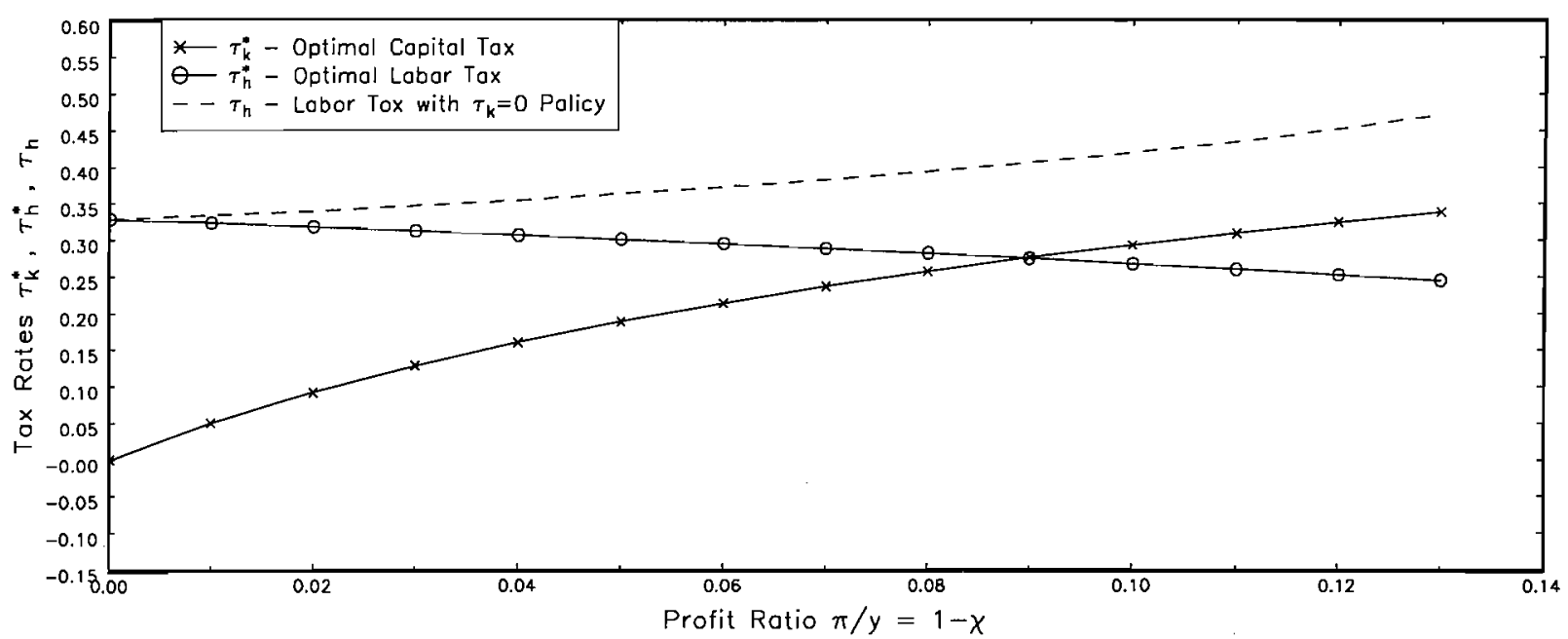

Fig 3: TAX RATES vs PROFIT RATIO

Double Tax an Dividends $\gamma=2$

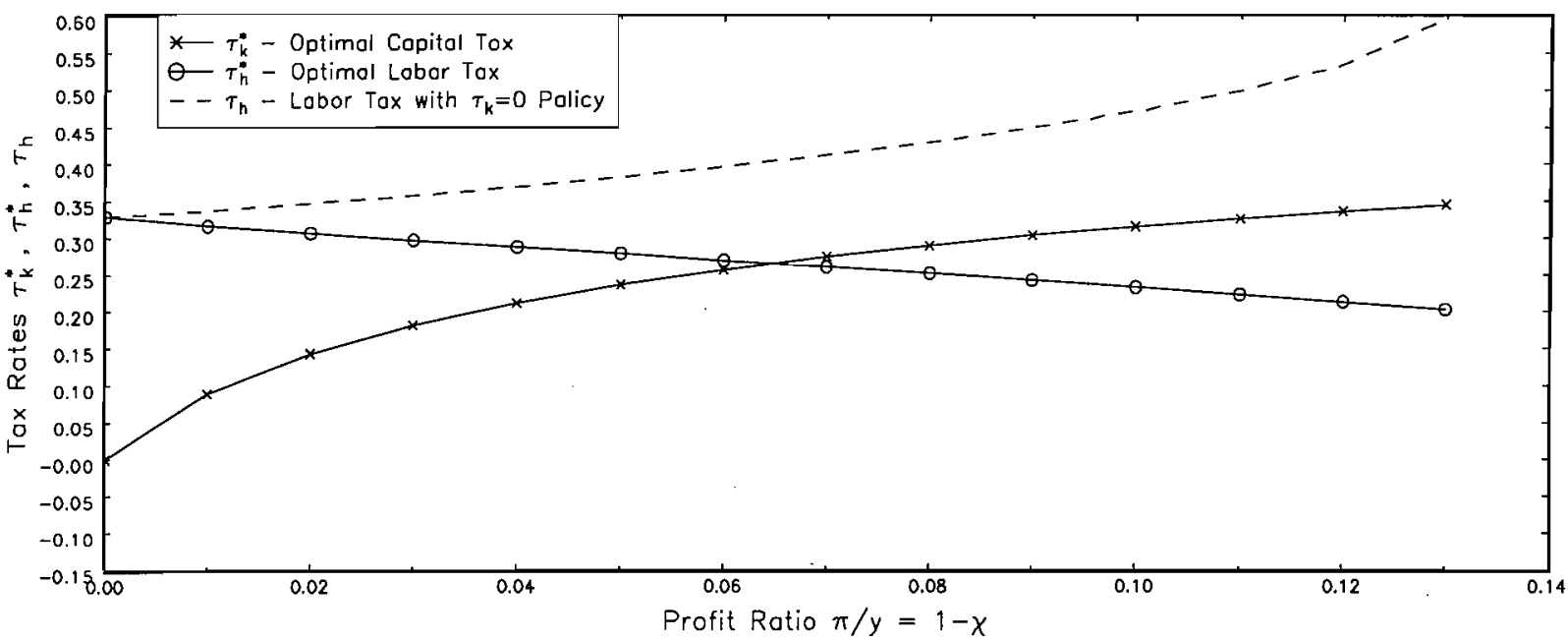


Fig 4: WELFARE LOSS FROM $\tau_{k}=0$ POLICY

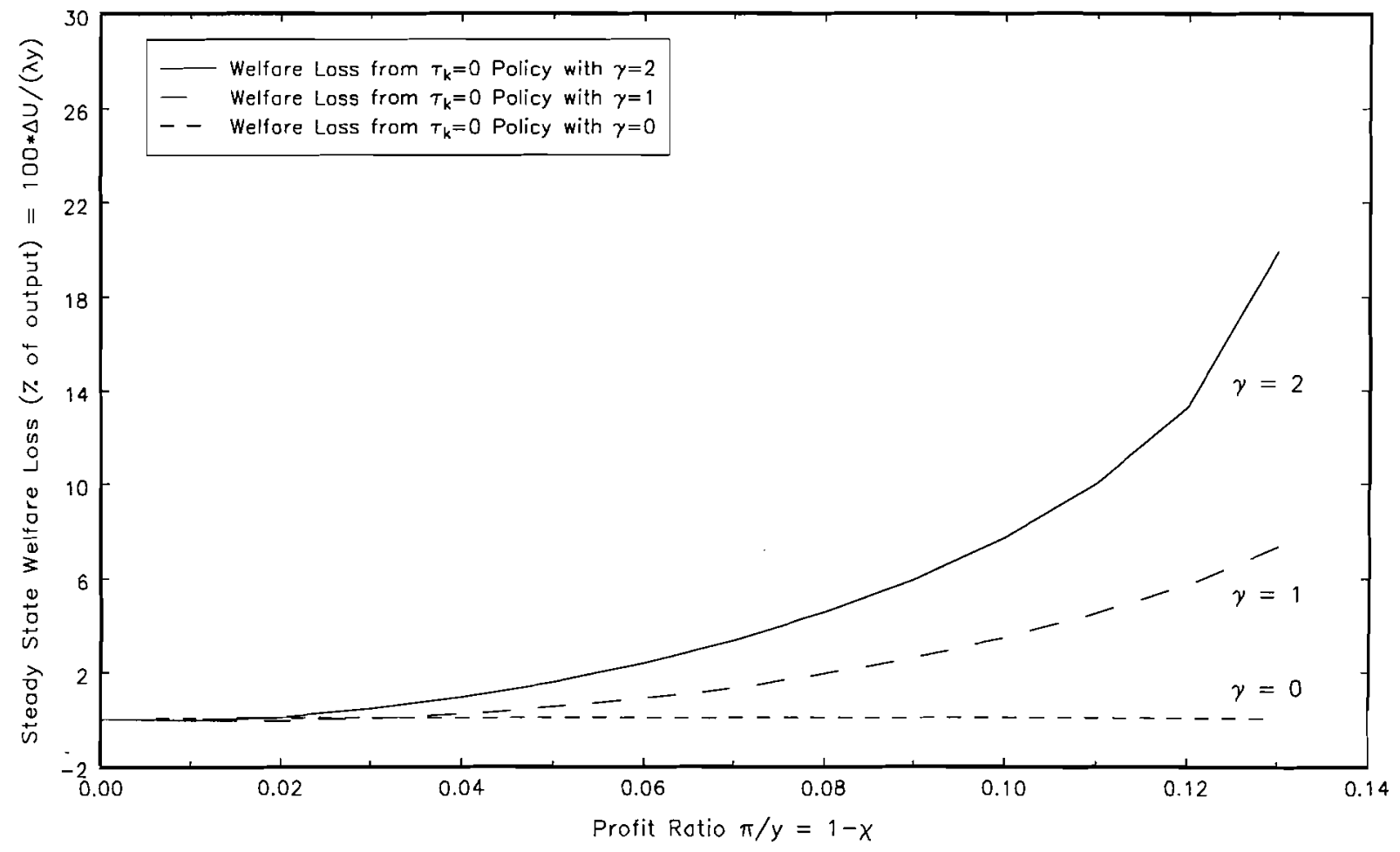

SOURCE: Authors' calculations. 